\title{
Historical Continuum in Bahamian Literary Thought
}

\author{
A. Marie Sairsingh \\ English Studies \\ University of The Bahamas
}

\section{Abstract}

The works examined in this paper include Patrick Rahming's "Slave Name", written in the Bahamian post-independence era; Obediah Michael Smith's "Wax Paper People" (2003), and Patricia Glinton-Meicholas's "No Vacancy in Paradise" (2001). I place these works on a continuum of discursive engagement with weighty questions of ontology, existentiality, and the still profound deliberations on the issue of freedom, arguing that these works reflect an ongoing engagement with how history has shaped, and continues to shape the Bahamian identity, and the Afro-Bahamian identity more specifically.

This paper examines the work of three Bahamian poets and argues that the respective authors' engagement with history is part of a larger Caribbean literary tradition, which has produced a prodigious body of literary works - in all genres - as well as an impressive output of significant literary and cultural theory. For writers at the vanguard of literary nationalism, history was a highly contested category, given the ontological obscurity of the Afro-Caribbean subject in the Euro-centred history of the day, and constituted a central theme in the literary and theoretical works of such writers as Lamming, Naipaul, Brathwaite, Walcott, and Harris. These writers all engaged what Baugh termed the "quarrel with history," the imperative to determine, locate, and interject the self in the trajectories of colonial historical narrative. Among this group, history has spawned significant and sustained debate. The attempt on the part of these writers to return to the "point of entanglement," the historical juncture of European-African collision in the anguished space of the New World, has yielded a range of responses.

The emergence of corrective Anglophone Caribbean historiographies and literary and cultural theories, and the materialization of previously unarticulated stories rendered from the perspective of subjects rather than objects of history, constitutes a significant corpus. While these projects fill the significant lacuna in the indigenization of these disciplines within the region, and provide important revisions of earlier Eurocentred texts, they also open fruitful ground for further interrogation and exploration of the being, existence and freedom of the historical and contemporary Caribbean/Bahamian subject.

The works under examination here include Rahming's "Slave Name," written in the Bahamian post-independence era; Smith's "Wax Paper People" (2003), and GlintonMeicholas's "No Vacancy in Paradise" (2001). I place these works on a continuum of discursive engagement with weighty questions of ontology, existentiality, and the still profound deliberations on the issue of freedom, arguing that these works reflect an

(c) A. M. Sairsingh, 2018. https://orcid.org/0000-0003-3119-0583

(C) International Journal of Bahamian Studies, 2018. https://doi.org/10.15362/ijbs.v24i0.311 
ongoing engagement with the ways in which history has shaped, and continues to shape the Bahamian identity, and the AfroBahamian identity more specifically.

In Rahming's poem "Slave Name," the poet asserts his indisputable right to his name, his heritage, his lineage, his ancestry, all of which are elemental to the formation of a wholesome Afro-Bahamian identity. Rahming implicitly critiques the systematic displacement of the Afro-Bahamian subject who, in consequence of the brutal legacy of slavery, and later, of colonial education, has internalized the colonizer's history, customs, traditions, and mores at the erasure of his own:

I know great-great grumpa was slave

I ain' like it but is so

But even slave gat hist'ry too

An' I gat a aright to know

What tribe I come from

Where they live

What was my famb'ly name

I know dat 'bout the master

The slave deserve the same

Rahming's project involves the creation of an ontology of time that can redress the abbreviated and truncated history of the African diasporic subject. He writes:

Our hist'ry ain' jest start here late

We wasn't always slave

An what I wouldn't give ta know

How my folks uset'a live

B'fore the trip from Africa

B'fore the drumbeat change

B'fore old man cry fuh loss

B'fore the trees was strange

In a sense, Rahming attempts to dislocate Western conceptions of time structured and defined by conquest. He seeks to know a history which, while profoundly affected by the fact of conquest, is not defined by it. Rahming is concerned with presenting an alternative to received colonial history and subverting the temporality marked with the designations "pre-colonial," "colonial," and "postcolonial." The poem continues:

I know all 'bout the King and Queen

And who succeed the throne

I study English Civil War

Jest like it was my own

And I could trace some English name

Back ta the Norman War

Yet still ain' no-one wan me ax

What was my name b' fore

The chasin' and the catchin'

The sellin' without shame

That ain' too much ta ax for, suh

I just wan' know my name

Rahming's acknowledgement of the rupture occasioned by the transatlantic slave trade is not the terminus of his discourse. Indeed, his poem is not a lament; Rahming, like Harris, rather than indulging in the recriminations that memory elicits, refigures loss and destruction wrought by history and uses the inventiveness of the imagination to enable the re-charting and recovery of history, thus providing the means to bridge the discontinuity induced by historical trauma. The poet asserts his right to his history, and to locating himself as subject, not object of that history. This uncompromising self-assertion, magnified within the collective Bahamian social and political milieu, reached its apex in the country's attainment of Black majority rule and later, independence. It represented an invigorated consciousness, more specifically, an Afro-Bahamian consciousness that appeared to engender a deep sense of pride in the country's historically maligned or occluded African heritage. Yet, ironically, this pride in one's Black heritage is later stretched to tenuousness at the very least, or is transmuted into a complex and paradoxical 
figuration revealing a deep ambivalence, as Bahamians contend with a tourist economy that encourages self-erasure.

This ambivalence, or more specifically, this paradox of self-assertion/self-negation, is exemplified in Smith's poem "Wax Paper People," which speaks to the exigencies of contemporary Bahamian life in a tourismdriven economy and responds to psychic consequences wrought by an industry whose capitalist imperative often exacts from its workers the price of virtual invisibility. Nixon (2015) observes that "tourism is one of the largest sites of neo-colonialism, shaping economic realities and national culture" (p. 3), and that, as such, writers and artists "grapple with the continued exploitation of colonialism found in the industry" (p. 4). Smith's poem harks back to this 500 year history of colonialism and to what Ian Strachan identifies as "the imperialist-colonial economy of wealth extraction and exploitation and an often antiimperialist counter-economy, one that concerns self-worth" (Strachan, 2002, p. 4). Smith thematises the deleterious effect of this mega-industry that exalts the Bahamas as paradise, and simultaneously destabilizes or negates the identity of its Afro-Bahamian inhabitants. Smith writes:

Shut y'ur mout,

Der touris' comin'!

What ya talkin' bout

Bein' Black for?

'bout strikin' back for?

You 'een wan' der man

An 'e wife spen' dey

Dollar, ah?

Ya wan' run um away, ah?

What ya wan' be Black

For anyway?

Hard hair so bad

Ya better straighten um
The bold assertion of Black Bahamian identity seen in Rahming's poem "Slave Name," seemingly recoils in this poem under the weight of the economic imperatives of tourism. Smith critiques the commodification of the country for tourist consumption; he critiques also the expected conformity of tourism service workers to the dictates of the industry, echoing Derek Walcott's observation that "the islands [of the Caribbean] sell themselves" at the price of "the seasonal erosion of their identity" (pp. 31-32). Pride in one's identity, in one's physiognomy, becomes superseded by acquiescence to the tenets of the industry and the containment of the Black self. Smith writes:
Won' be ya se'f -
Can' be ya se'f
When disguise ga put
Money in der treasury...
disguise so deep, so good,
so long/ Bahamian man nor woman
remember dey actual look
dey natural se'f.

Smith thus highlights, through his use of irony, the struggle of the tourist worker to retain the integrity of racial, national and personal identity while contending with the neo-colonial exploitation of the tourism industry. The foregoing stanzas impel contemplation of the ways in which racial formation as a sociohistorical and transhistorical process occurred during the colonial era, and how these colonial vestiges have affected the formation of personal and national consciousness within the contemporary moment. For while in the national rhetoric of earlier years Black identity was loudly and unapologetically proclaimed, this voice has become somewhat muted and, in fact, the dualistic self-assertion/self-negation paradigm has continued to operate, lamentably, to the 
point of normalizing the self-negating practice of modifying appearance to suppress or 'tame' visible blackness, so that, as Smith asserts, we do not "fri'ten der touris'/der bread \& butter/off der table."

In the penultimate stanza, Smith presents an existential dilemma: the disavowal or containment of Black identity that may secure the tourist dollar or the assertion of the Black self that may chase the frightened tourist away. He concludes ironically with the poignant question,

You choose!

In' it better ta be transparent,

So people could walk

Right tru ya

Don' even see ya?

The poet invokes the dilemma of choice- to negate self, to be rendered invisible, in the interest of economic gain. Invisibility here resonates with Ralph Ellison's novel Invisible Man, which, arguably, teeters discursively between a rhetoric of despair and anatomizing Black existentiality in ways that potentiate liberation. I would argue that Smith's rhetoric, rather than suggesting resignation as a choice, asserts the imperative of recovering one's identity, one's self. I read his poetics as engaging a philosophical gaze, insisting upon the validation of the Black Bahamian subject's humanity, on the reclamation of Black ontology.

This concept of reclaiming Black ontology loudly resonates in the work of GlintonMeicholas, whose poem, "No Vacancy in Paradise" exists on the continuum of the two previously discussed works. The poem reflects the author's awareness of history as the centrally creative force in forging Bahamian selfhood. Like Nettleford, Glinton-Meicholas also recognizes that "neither artist nor academic can function adequately without a sense of history or the importance of that history to the existential realities of contemporary Caribbean life" (Nettleford, 2013, p. 282), and her poetry reflects this awareness. Glinton-Meicholas interlaces articulations and understandings of history into her poetics. For example, her tropology, which draws upon historical elements, plantation images, and brochuristic images of paradise, demonstrates how tourism discourse, as Ian Strachan has argued, can be seen as an extension and reflection of plantation discourse.

Glinton-Meicholas begins:
We accept
For now
We must
Pick up cotton towels and
Plough corn rows
Into silk cotton hair.

The clever punning, and word play present the compressed image of plantation labour and present-day tourism labour as one and the same enterprise. Glinton-Meicholas sees equivalencies in cotton plantation labour and hotel domestic labour, weaving them into a single image. Similarly, ploughing corn and braiding tourists' hair are conveyed as comparable labour. If there is a sense of worker resignation to this neo-plantation system in the opening stanza, it is provisional, since the operative phrase, "for now" implies the biding of time, waiting for the right moment, for a revised consciousness.

The poem speaks to the experiences of the socially and discursively marginalized, the tourist workers, who hang on the lower rungs of the tourism industry that, according to Strachan, propagates and exploits the paradise myth (2003, p. 3). GlintonMeicholas gives representation to those who labour in this modern day plantation. She writes: 
Forgive us, though

If our humanity

Intrudes

Spoiling

The fantasies

Packaged for you

By a dream merchant

Into fournightsthreedays

Of tropical delights

John B. Sailing

Swaying palms

Wailing guitars

Picturesque pickaninnies

Posing for alms

Beaches by the mile

Sparking white

Cheshire cat smiles

Devoid of thought

And embarrassing flesh

Save for arms bought

To spin trays under the limbo stick

Or place umbrellas

To shade skin that wilts

Under the tropic sun

The poet presents a series of visual, auditory, and kinesthetic images - attractive land and seascapes; sailboats gliding on the water; musicians plucking and strumming favourite guitar riffs; hotel workers charged with serving, entertaining, and waiting on tourists, delivering the paradise fantasies. Counterpoised with these images are those of "picturesque pickaninnies" begging for alms, whose ornamental presence obfuscates the reality of poverty not intended for visitors to see. There, too, are the workers whose humanity threatens to "intrude" upon the scene, challenging the image of the smiling, acquiescent Black native whose raison d'etre is to fulfil the fantasy propagated by the dream merchant.

The final stanza of the poem reads:

No, there's no vacancy in paradise

We are claiming all the rooms

Willing only to lend space

To those who take with due respect

The role of gracious guest.

Angelique Nixon's theoretical concept of resistance to paradise is exemplified in Glinton-Meicholas' work, which offers an alternative model of tourism that is "less exploitative and rooted in African diasporic identity and cultural practices" (Nixon, 2015 , p. 4). This resistance to the dehumanizing practices of the present tourism model thus mobilizes a discourse of being and ontology, bringing into focus the need, as Bogues (2010) has expressed it, to "work through the politics of the wound of racial slavery and racial domination, not as historical memory, but as present past" (p. $65)$.

The works of the writers examined here make important contributions to the ongoing national, regional, and global discussion around the legacy of the transatlantic slave trade and the myriad ways that this legacy continues to impact the contemporary moment. These writers explore Bahamian existential reality and speak to the need for a clearer articulation of Bahamian identities, and the need for cultural enunciations that are sensitive to the ways in which history shapes our sense of identity and belonging. These works therefore collectively inform the national ethos, and contribute to the discourse not only of what it means to be Bahamian, but, more deeply, what it means to be human. 


\section{References}

Baugh, E. (2012). The West Indian writer and his quarrel with history. Small Axe, 38, 60-74. https://doi.org/10.1215/079905371665677

Bogues, A. (2010). Empire of liberty: power, desire and freedom. Hanover, $\mathrm{NH}$ : University Press of New England.

Ellison, R. (1952). Invisible man. New York, NY: Random House.

Glinton-Meicholas, P. (2001). No vacancy in paradise: A collection of poems. Nassau, Bahamas: Guanima Press.

Nettleford, R. (2013). Cultural identity and the arts: New horizons for Caribbean social sciences? In Y. Hume \& A. Kamugisha (Eds.), Caribbean cultural thought: From plantation to diaspora (pp. 275-289). Kingston, Jamaica: Ian Randle Press.

Nixon, A. (2015). Resisting paradise: Tourism, diaspora and sexuality in Caribbean culture. Jackson: University of Mississippi Press.

Rahming, P. (1993). Slave name. In I. S. Cabrera (Ed.), From the shallow seas: Bahamian creative writing today. Havana, Cuba: Casa de las Americas.

Smith, O. M. (2003). Wax paper people. In Poems to sit on to shell peas (pp. 68-69). Nassau, Bahamas: Verse Place Press.

Strachan, I. G. (2002). Paradise and plantation: Tourism and culture in the anglophone Caribbean. Charlottesville: University of Virginia Press.

Walcott, D. (1993). The Antilles. New York, NY: Farrar, Straus and Giroux. 